\title{
Mycofungicide: Trichoderma Based Preparation for Foliar Applications
}

\author{
Gyula Oros ${ }^{1}$, Zoltán Naár ${ }^{2}$ \\ ${ }^{1}$ Plant Protection Institute HAS, Budapest, Hungary \\ ${ }^{2}$ NARIC Food Research Institute, Budapest, Hungary \\ Email: gyula.oros@gmail.com,z.naar@crfri.hu
}

How to cite this paper: Oros, G. and Naár, Z. (2017) Mycofungicide: Trichoderma Based Preparation for Foliar Applications. American Journal of Plant Sciences, 8, 113-125. http://dx.doi.org/10.4236/ajps.2017.82009

Received: November 24, 2016

Accepted: January 16, 2017

Published: January 19, 2017

Copyright ( $) 2017$ by authors and Scientific Research Publishing Inc. This work is licensed under the Creative Commons Attribution International License (CC BY 4.0).

http://creativecommons.org/licenses/by/4.0/

\begin{abstract}
The Trichoderma based emulsifiable mycofungicide for controlling foliar diseases lessened the yield loss to economically acceptable level with significant increase of the quality of product. The amount of phylloplane originated $T$. harzianum and T. parceramosum strains containing liquid formulation, to be applied as leaf spray, might be reduced in two order of magnitude as compared to the solid preparations to achieve the same effect. Both sensitivity of 13 phytopathogenic fungi to antifungal properties of toxic substances released by 32 Trichoderma strains and their susceptibility to the same were examined during development of new mycofungicide. Both toxin production of Trichodermas and the sensitivity of target fungi varied within large limits, being $P y$ thium irregulare the most, while Phytophthora infestans and Macrophomina phaseolina the less tolerant. The sensitivity responses of fungi to toxins correlated to their susceptibility to antagonists. The spectrum of antagonists of pathogenic fungus or targets of Trichoderma strain proved to be unpredictable. Conidia of Trichoderma strains in liquid paraffin (LP) of pharmaceutical quality (LP PQ) survived over 2 years. However, in commercial LP the shelf life of them significantly decreased in strain dependent manner, and the presence of emulsifiers selectively reduced the survival rate as well. The LP PQ was not phytotoxic in therapeutic doses, but commercial LP proved to be toxic when applied as leaf spray independently on the emulsifiers. Both fungitoxic and phytotoxic contaminants of commercial LP could be eliminated with activated carbon.
\end{abstract}

\section{Keywords}

Mycofungicide, Trichoderma, Rosa, Diplocarpon, Pepper, Phytophthora

\section{Introduction}

The observation of antagonistic properties T. virens [1] promoted efforts to ex- 
plore this feature for controlling phytopathogenic fungi [2]. Nowadays biology of this genus is intensively studied and various strains are used in diverse fields of human practices [3] [4] [5]. Examination of numerous strains revealed that the antagonism is a common property of Trichoderma species and they usually can parasite the phytopathogenic fungi [3] [6] [7] [8], although these features are strongly influenced by environmental conditions [9] [10]. Since discovery of Weidling [1] large Trichoderma based industry has been developed, and diverse ways of their use have been patented (Table 1) as well as several hundred Trichoderma based preparations have been commercialized to prevent yield losses caused by phytopathogenic microbes [11]. These mycofungicides - mostly selected strains of $T$. harzianum and $T$. viride - perform well both in laboratory and model applications, but sometimes are less effective in the field where strains must tolerate a wide range of climatic, edaphic and biotic factors [10] [12] [13] [14]. We should remark that some T. harzianum strains seemingly are in reality $T$. asperellum, thus the taxonomic position of strains needs verification applying recent molecular methods [15].

About four fifths of commercialized Trichoderma formulations are wettable powders or granules containing dried propagules (conidia and chlamydospores)

Table 1. Number of patents applied on the use of various Trichodermas.

\begin{tabular}{ccccc}
\hline Trichoderma spp. & Section $^{\mathrm{a}}$ & Clade & $\mathrm{A}^{\mathrm{b}}$ & $\mathrm{B}$ \\
\hline asperellum & $\mathrm{P}$ & 13-hamatum & 30 & 9 \\
atroviride & $\mathrm{T}$ & 12-viride & 52 & 19 \\
citrinoviride & $\mathrm{L}$ & 14-longibrachiatum & 14 & 0 \\
gamsii & $\mathrm{P}$ & $?$ & 2 & 0 \\
ghanense & $\mathrm{L}$ & 14-longibrachiatum & 8 & 0 \\
hamatum & $\mathrm{P}$ & 13-hamatum & 88 & 31 \\
harzianum & $\mathrm{P}$ & 1-harzianum & 1170 & 108 \\
jecorina & $\mathrm{L}$ & 14-longibrachiatum & 306 & 7 \\
koningii & $\mathrm{T}$ & 12-viride & 748 & 27 \\
longibrachiatum & $\mathrm{L}$ & 14-longibrachiatum & 1007 & 12 \\
parceramosum & $\mathrm{L}$ & 14-longibrachiatum & 93 & 0 \\
piluliferum & $\mathrm{P}$ & 9-pachybasioides & 3 & 1 \\
polysporum & $\mathrm{P}$ & 9-pachybasioides & 122 & 7 \\
pseudokoningii & $\mathrm{L}$ & 14-longibrachiatum & 93 & 13 \\
reesei & $\mathrm{L}$ & 14-longibrachiatum & 2136 & 28 \\
saturnisporum & $\mathrm{L}$ & 14-longibrachiatum & 40 & 1 \\
tomentosum & $\mathrm{P}$ & 14-longibrachiatum & 8 & 0 \\
virens & $\mathrm{P}$ & 2-virens & 227 & 62 \\
All together & 3 & 5 & 7240 & 246 \\
\hline
\end{tabular}

asections: $\mathrm{L}=$ Longibrachiatum, $\mathrm{P}=$ Pachybasium, $\mathrm{T}=$ Trichoderma. ${ }^{\mathrm{b}}$ The number of cases where the species was mentioned (A) and patents (B) of preparations used for biocontrol in database of US Patent Office since 1790 . 
of a given concentration to be mixed with water or diluted with suitable solid material prior to use [16], and applied by diverse methods [11]. The rate of use varies between $50-300 \mathrm{~kg} \cdot \mathrm{ha}^{-1}$ that is realistic for soil applications of homemade products to be used in small plots [16] but hinders both their wholesale marketing and expansive use in big farms. The narrow compatibility of eubiotic biocides with pesticides containing synthetic active ingredients also limits their integration into recent pest management programs with special regard to their application against canopy threatening pathogens, where the use of modern synthetic pesticides is inevitable due to the required high sureness of the protective effect (ornamental plants, leafy vegetables, fruits etc.). In the cases of integrated use the sensitivity of the antagonist to inert ingredients (surfactants, liquid or solid carriers, etc.) can also be a restricting factor [14]. Nevertheless, the liquid formulations containing Trichoderma propagules has great advantages thus we started to develop an eubiotic preparate based on organic carrier that might open a possibility to decrease the specific rate of use and the foliar application of such biofungicide. The response of phytopathogenic fungi to toxic compounds released by Trichoderma strains of various taxonomic position as well as the survival of Trichoderma conidia in liquid preparations were examined in model experiments for selection of appropriate strain useable in biocontrol practices [17].

Here we present our experiences of the development and promising results hoping to promote further work in this field.

\section{Material and Methods}

\subsection{Fungi}

The fungi listed in Table 2 were maintained on potato dextrose agar slants at $22^{\circ} \mathrm{C}-25^{\circ} \mathrm{C}$ (CM0139B, OXOID, Basingstoke) amended with $2 \mathrm{~g} \cdot \mathrm{L}^{-1}$ casein digest (Difco, Detroit, USA), vitamins (pyridoxine $\mathrm{HCl}$, thiamin $\mathrm{HCl}$, riboflavin and nicotinamide at 1.0, 10.0, 1.0 and $20.0 \mathrm{mg} \cdot \mathrm{L}^{-1}$, respectively) mineral salts $\left(\mathrm{KCl}, \mathrm{KH}_{2} \mathrm{PO}_{4}, \mathrm{~K}_{2} \mathrm{HPO}_{4}\right.$ and $\mathrm{MgSO}_{4}$ at $10,12,0.5,0.5,0.5$ and $0.5 \mathrm{~g} \cdot \mathrm{L}^{-1}$, respectively). All strains were from the Mycology Collection (WDCM824) of the Plant Protection Institute, Hungarian Academy of Sciences (Budapest, Hungary).

\subsection{Biological Tests}

Toxicity tests: The conidia of Trichoderma were washed up with sterile distilled water containing $0.05 \%$ Tween 20 of 8 days old colonies grown up on milk agar to produce conidia for inoculation of agar plates. The suspension of conidia $(\approx 5$ $\times 10^{5}$ cell $\left.\mathrm{mL}^{-1}\right)$ was mixed up with potato dextrose agar $\left(45^{\circ} \mathrm{C}-50^{\circ} \mathrm{C}\right)$ prepared as above $(1+10 \mathrm{~mL})$ and dispensed into Petri dishes $(90 \mathrm{~mm} \varnothing)$. After 16 hours incubation $10 \mathrm{~mL}$ of Trypton B containing agar solution (2 and $10 \mathrm{~g} \cdot \mathrm{L}^{-1}$, respectively) was over layered than centrally inoculated with mycelium disc $(3.5 \mathrm{~mm}$ $\varnothing)$ cut of three days old colony of phytopathogenic fungi grown up on PDA as above at $22^{\circ} \mathrm{C}-24^{\circ} \mathrm{C}$. Response of Pythium and Phytophthora was tested on Green Pea Agar prepared as described earlier [18] at $15^{\circ} \mathrm{C}-18^{\circ} \mathrm{C}$. Diameter of 
Table 2. (a) Sensitivity response of fungi to Trichoderma toxins; (b) Sensitivity response of fungi to Trichoderma toxins.

(a)

\begin{tabular}{|c|c|c|c|c|c|c|c|c|}
\hline \multirow{2}{*}{$\begin{array}{l}\text { Trichoderma and } \\
\text { Hypocrea species }\end{array}$} & \multirow{2}{*}{$\mathrm{C}^{\mathrm{a}}$} & \multicolumn{7}{|c|}{ Test Fungi ${ }^{\mathrm{b}}$} \\
\hline & & $\mathrm{A}$ & B & $\mathrm{C}$ & $\mathrm{D}$ & $\mathrm{E}$ & F & G \\
\hline T. aureoviride & B-318 & 43 & 69 & 84 & 63 & 97 & 52 & 8 \\
\hline T. citrinoviride & B-311 & 83 & 78 & 62 & 100 & 81 & 76 & -13 \\
\hline T. longibrachiatum & B-313 & 88 & 90 & 96 & 91 & 76 & 88 & 55 \\
\hline T. pseudokoningii & B-312 & 38 & 83 & 11 & 74 & 68 & 84 & 29 \\
\hline H. jecorina & B-301 & 40 & 164 & 18 & 100 & 82 & 12 & 40 \\
\hline T. reesei & B-314 & 30 & 73 & 44 & 88 & 64 & 32 & -25 \\
\hline T. ghanense & B-305 & 83 & 88 & 98 & 100 & 56 & 80 & 38 \\
\hline T. parceramosum & B-328 & 98 & 73 & 85 & 92 & 96 & 56 & 50 \\
\hline T. parceramosum & B-315 & 77 & 80 & 85 & 90 & 92 & 40 & 50 \\
\hline T. saturnisporum & B-316 & 78 & 45 & 62 & 100 & 70 & 80 & 45 \\
\hline T. piluliferum & B-306 & 70 & 89 & 80 & 100 & 97 & 28 & 53 \\
\hline T. polysporum & B-307 & 83 & 86 & 82 & 100 & 97 & 88 & 50 \\
\hline T. hamatum & B-308 & 22 & 40 & 0 & 60 & 66 & 0 & 13 \\
\hline T. harzianum & B-309 & 90 & 88 & 98 & 100 & 97 & 68 & 50 \\
\hline T. harzianum & B-075 & 78 & 84 & 98 & 100 & 95 & 64 & 48 \\
\hline T. harzianum & B-325 & 78 & 80 & 80 & 100 & 95 & 64 & 49 \\
\hline T. harzianum & B- 408 & 92 & 90 & 100 & 100 & 97 & 80 & 50 \\
\hline T. harzianum & B-317 & 100 & 83 & 85 & 100 & 85 & 76 & 53 \\
\hline T. longipile & B-338 & 53 & 84 & 76 & 76 & 100 & 100 & 100 \\
\hline T. minutisporum & B-339 & 63 & 95 & 98 & 100 & 100 & 100 & 100 \\
\hline T. strictipile & B-332 & 80 & 84 & 91 & 93 & 100 & 100 & 40 \\
\hline T. tomentosum & B-331 & 85 & 93 & 95 & 94 & 100 & 100 & 49 \\
\hline T. virens & B-310 & 20 & 40 & 25 & 82 & 96 & 28 & 50 \\
\hline T. atroviride & B-320 & 97 & 93 & 96 & 94 & 92 & 60 & 50 \\
\hline T. atroviride & B-396 & 95 & 93 & 100 & 96 & 92 & 68 & 50 \\
\hline T. koningii & B-322 & 13 & 38 & 5 & 64 & 81 & 4 & 3 \\
\hline T. strigosum & B-340 & 82 & 88 & 78 & 89 & 100 & 100 & 100 \\
\hline T. viride & B-319 & 78 & 83 & 38 & 88 & 83 & 68 & -25 \\
\hline H. muroiana & B-302 & 85 & 76 & 87 & 100 & 90 & 32 & 15 \\
\hline H. muroiana & B-303 & 85 & 76 & 80 & 100 & 87 & 60 & 3 \\
\hline H. muroiana & B-304 & 83 & 79 & 84 & 100 & 89 & 68 & 11 \\
\hline T. spirale & B-333 & 73 & 84 & 95 & 93 & 100 & 100 & 28 \\
\hline
\end{tabular}

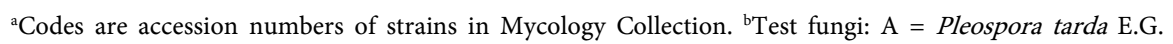
Simmons, B = Alternaria solani Sorauer, $\mathrm{C}=$ Cochliobolus carbonum R.R. Nelson, D = Macrophomina phaseolina (Tassi) Goid., E = Sclerotinia sclerotiorum (Lib.) deBary, F = Verticillium albo-atrum Reinke et Berthold, $\mathrm{G}=$ Fusarium venenatum Nierenberg. 
(b)

\begin{tabular}{|c|c|c|c|c|c|c|c|c|c|}
\hline \multirow{2}{*}{$\mathrm{N}$} & \multirow{2}{*}{$\begin{array}{l}\text { Trichoderma and } \\
\text { Hypocrea species }\end{array}$} & \multirow{2}{*}{$\mathrm{O}^{\mathrm{a}}$} & \multirow{2}{*}{$S^{b}$} & \multicolumn{6}{|c|}{ Test Fungi ${ }^{\mathrm{b}}$} \\
\hline & & & & $\mathrm{H}$ & I & $\mathrm{J}$ & $\mathrm{K}$ & $\mathrm{L}$ & M \\
\hline 1 & T. aureoviride & $\mathrm{K}$ & H01 & 0 & 63 & 28 & 0 & 0 & 23 \\
\hline 2 & T. citrinoviride & $\mathrm{T}$ & L01 & 47 & 100 & 95 & 0 & 64 & 68 \\
\hline 3 & T. longibrachiatum & $\mathrm{T}$ & L02 & 9 & 100 & 100 & 95 & 95 & 91 \\
\hline 4 & T. pseudokoningii & $\mathrm{T}$ & L03 & 100 & 76 & 100 & 32 & 0 & 0 \\
\hline 5 & Hypocrea jecorina & K & L04 & 0 & 92 & 0 & 0 & 0 & 0 \\
\hline 6 & T. reesei & Ind & L05 & 0 & 11 & 100 & 98 & 31 & 77 \\
\hline 7 & T. ghanense & $\mathrm{T}$ & L06 & 0 & 100 & 100 & 100 & 100 & 85 \\
\hline 8 & T. parceramosum & $D r$ & L07 & 0 & 82 & 0 & 12 & 0 & 0 \\
\hline 9 & T. parceramosum & Ind & L08 & 7 & 100 & 100 & 98 & 73 & 45 \\
\hline 10 & T. saturnisporum & $\mathrm{T}$ & L09 & 0 & 100 & 92 & 0 & 7 & 77 \\
\hline 11 & T. piluliferum & $\mathrm{T}$ & P01 & 9 & 100 & 95 & 62 & 100 & 85 \\
\hline 12 & T. polysporum & $\mathrm{T}$ & P02 & 14 & 92 & 100 & 100 & 72 & 82 \\
\hline 13 & T. hamatum & $\mathrm{T}$ & P03 & 0 & 0 & 0 & 0 & 0 & 0 \\
\hline 14 & T. harzianum & $\mathrm{T}$ & P04 & 14 & 100 & 100 & 100 & 100 & 92 \\
\hline 16 & T. harzianum & K & P05 & 13 & 58 & 100 & 35 & 100 & 95 \\
\hline 17 & T. harzianum & $R a$ & P06 & 0 & 95 & 96 & 0 & 28 & 48 \\
\hline 18 & T. harzianum & $R a$ & P13 & 21 & 100 & 100 & 100 & 93 & 95 \\
\hline 19 & T. harzianum & Rs & P07 & 3 & 87 & 100 & 95 & 85 & 95 \\
\hline 20 & T. longipile & $\mathrm{K}$ & P08 & 3 & 100 & 99 & 23 & 100 & 78 \\
\hline 21 & T. minutisporum & $\mathrm{K}$ & P09 & 0 & 100 & 100 & 100 & 0 & 100 \\
\hline 22 & T. strictipile & K & $\mathrm{P} 10$ & 0 & 100 & 72 & 8 & 24 & 42 \\
\hline 23 & T. tomentosum & K & P11 & 0 & 84 & 68 & 35 & 60 & 74 \\
\hline 24 & T. virens & $\mathrm{T}$ & P12 & 100 & 76 & 0 & 0 & 0 & 0 \\
\hline 25 & T. atroviride & $\mathrm{T}$ & T01 & 27 & 100 & 100 & 0 & 75 & 71 \\
\hline 26 & T. atroviride & $C l$ & T02 & 0 & 100 & 100 & 78 & 87 & 89 \\
\hline 27 & T. koningii & $\mathrm{T}$ & T03 & 0 & 47 & 0 & 0 & 31 & 0 \\
\hline 28 & T. strigosum & $\mathrm{T}$ & T04 & 0 & 95 & 7 & 48 & 73 & 48 \\
\hline 29 & T. viride & $\mathrm{T}$ & T05 & 0 & 82 & 0 & 100 & 0 & 8 \\
\hline 30 & H. muroiana & $\mathrm{Le}$ & T06 & 14 & 100 & 89 & 86 & 60 & 77 \\
\hline 31 & H. muroiana & $A m$ & T07 & 0 & 100 & 53 & 0 & 0 & 11 \\
\hline 32 & H. muroiana & Le & T08 & 0 & 100 & 33 & 0 & 0 & 35 \\
\hline 33 & T. spirale & $\mathrm{T}$ & N01 & 100 & 100 & 95 & 28 & 91 & 54 \\
\hline
\end{tabular}

arigin: $\mathrm{K}=$ bark, $\mathrm{T}=$ soil, $\mathrm{Ind}=$ industrial, $D r=$ stroma of Diplocarpon rosae F.A. Wolf, $R a=$ stroma of Rhytisma acerium (Pers.) Fr., Cl= Fusarium oxysporum Schltdl. infected Chionodoxa lucillae Boiss. bulb, $R s=$ pseudosclerotium of Rhizoctonia solani Kühn, Le = Lentinula edodes (Berk.) Pegler, $A m=$ rhizomorph

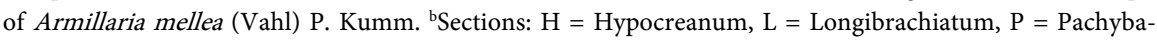
sium, $\mathrm{T}=$ Trichoderma, $\mathrm{N}=$ No lineage lineage, according to International Subcomission on Trichoderma and Hypocrea Taxonomy. ${ }^{\circ}$ Test fungi: $\mathrm{H}=$ Pythium irregulare Buism., $\mathrm{I}=$ Phytophthora infestans (Mont.) deBary., J = Waitea circinata Warcup et P.H.B., $\mathrm{K}=$ Rhizoctonia solani Kühn. AG-3, L = Rhizoctonia solani Kühn. AG-4, M = Rhizoctonia solani Kühn. AG-2. 
colonies was measured 24 and 48 hours later $\left(\mathrm{dT}_{24}\right.$ and $\left.\mathrm{dT}_{48}\right)$, and the rate of growth was expressed as a difference between diameters measured, and expressed in percent of diameters of fungi grown on Trichoderma free medium $\left(\mathrm{dC}_{24}\right.$ and $\left.\mathrm{dC}_{48}\right)$ : Inhibition rate $(\%)=100-\left[100^{*}\left(\mathrm{dT}_{48}-\mathrm{dT}_{24}\right) /\left(\mathrm{dC}_{48}-\mathrm{dC}_{24}\right)\right]$. Negative values mean stimulation of fungal growth.

Storage life test. The conidia of Trichoderma were washed up with paraffin oil (pharmacological quality) of 8 days old colonies grown up on milk agar then suspension was mixed up with $250 \mathrm{mg}$ of dry $\mathrm{MgSO}_{4}$ and $10 \mathrm{~min}$ later shaken up and filtered through glass filter (G-2). The conidia were separated of paraffin oil in centrifuge ( $5 \mathrm{~min}, 2000 \mathrm{rpm}$ ) and the sediment suspended subsequently with appropriate carrier material to achieve concentration $10^{8} \mathrm{cell} \cdot \mathrm{mL} \mathrm{L}^{-1}$ or $10^{9} \mathrm{cell} \cdot \mathrm{g}^{-1}$ than the prepared formulations were stored at usual conditions for pesticides. During first two week samples were taken each day and later weekly and the number of living cell was counted by ten and two-fold dilution series technique.

Preparation of eubiotic formulations was carried out following recipes described in examples of the patent application HPO 0800405 [17].

Treatment of plants. Watery suspensions or suspo-emulsions were made of formulations at appropriate concentrations and sprayed run off by usual manner. Their effect was evaluated either by measuring changes in yield or health state of plants treated.

Survival of Trichoderma in canopy was examined washing the surface of leaves and counting the number of propagules by ten and two-fold dilution series technique on Askew and Lang medium [19].

Detecting pathogens on pepper field was carried out by traditional manners: Disease symptoms were evaluated as well as samples of plant organs were taken and surveyed under dissecting microscope. The zoosporangia formed on leaves were transmitted onto the potato discs (cv. Desirée) to detect the presence of $P$. infestans. The selective media were used to reveal presence of Fusarium [20], Macrophomina [21], Pythium [22] and Rhizoctonia [23] in root necks, where the respective microbicides were replaced with metalaxyl $\left(100 \mathrm{mg} \cdot \mathrm{L}^{-1}\right)$, carbendazim $\left(50 \mathrm{mg} \cdot \mathrm{L}^{-1}\right)$, triadimefon $\left(20 \mathrm{mg} \cdot \mathrm{L}^{-1}\right)$ and kanamycin $\left(10 \mathrm{mg} \cdot \mathrm{L}^{-1}\right)$ to depress the respective microbes presented in samples. Propamocarb (100 mg. $\left.\mathrm{L}^{-1}\right)$ was used for differentiation between Pythium and Phytophthora.

\subsection{Data Analysis}

Fisher's test was applied to evaluate significance of differences between variants at $p=0.05$ level. The experimental data were analyzed with multivariate statistical methods where the basic data matrix (32 Trichoderma $\times 13$ test fungi) was transformed into probit values. Potency Mapping (PM) and Spectral Component Analysis (SCA) were employed to disclose differences between both antifungal activity of Trichodermas and sensitivity responses of test species following Lewi [24]. The SCA separates the basic data matrix into two part; the first is a vector proportional to overall strength of response (PM), while the second is a matrix of spectral components (SPM) characterizing the spectrum of activity or sensitivity. 
The Principal Component Analysis was applied to demonstrate the potential number of factors affecting the selective response of target fungi to toxic principles [24]. Cluster Analysis (CA) was carried out to reveal relationship among spectrum of activities of Trichoderma strains as spectral variables.

\section{Results}

The Trichoderma strains broke throw the agar layer after 72 hours in majority of cases, thus the growth of test fungi was altered only by metabolites excreted and diffused throw the agar layer. The growth inhibition rates are compiled in Table 2. The reproducibility of experiments was good, which means, both test fungi and Trichoderma strains grew near synchronously supporting the reliability of measurements $\left(\mathrm{F}_{\text {replication }}=1.91<\mathrm{F}_{0,05}=2.30\right)$.

\subsection{Antifungal Activity of Metabolites Released by Trichoderma Strains}

The strength of antifungal activity of Trichoderma metabolites varied in strain dependent manner, and differences between strains of the same species were in the level of differences between strains of strains of various sections (Figure 1).

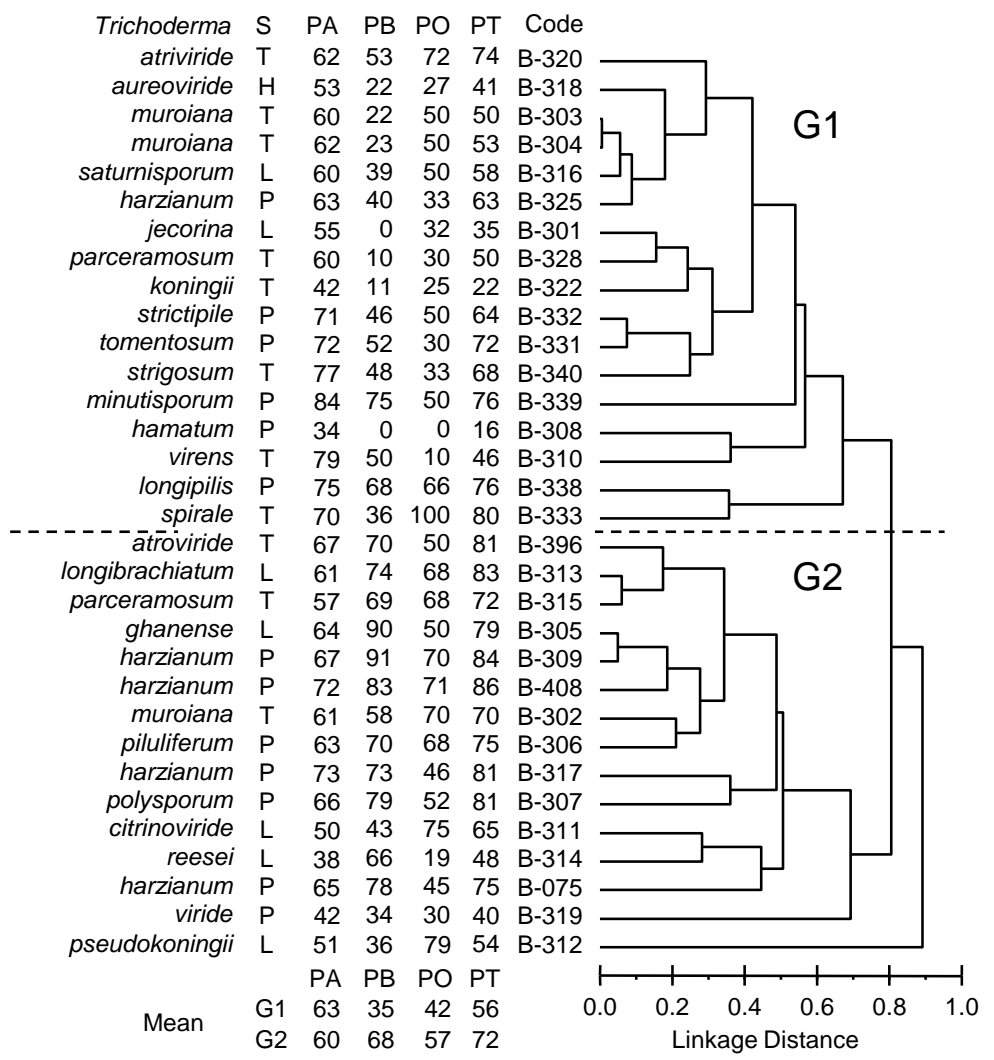

Figure 1. Cluster-diagram of the interrelationships between Trichoderma strains on the base of the antifungal efficacy of their metabolites released. Unweighted pair group average method based on Pearson's correlation coefficients of spectral component variables (Trichoderma strains) was applied to construct the clusterogram. The codes refer to strains as listed in Table 2. $\mathrm{S}=$ see Table 2. PA, PB and PO are potential activities against asco-, basidio- and oomycetaceous fungi, respectively. PT is the overall potential activity. 
For example, two strains of T. harzianum (B305 and B428) isolated of $R$. acerinum exhibited different potential activities against asco-, basidio- and oomycetaceous fungi. Trichoderma strains formed two groups (G1 and G2) when clustered applying selective growth responses of test fungi in dual cultures being the group G2 significantly more active $(p=0.005)$. The potential host range of these groups also altered being the strains of G1 group more active against asco- while those of G2 against basidiomycetaceous targets ( $p=0.001$ and 0.08 , respectively). However, the subclusters G1 and G2 were formed of strains of various sections, indicating that their taxonomic position did not relate to this groupping.

\subsection{Sensitivity Response of Test Fungi to Metabolites of Trichoderma Strains}

The sensitivity of target species varied within large limits, being the Pythium irregulare the most, while Phytophthora infestans and Macrophomina phaseolina the less tolerant ones among 13 phytopathogenic fungi tested (Table 2). Three major factors comprised $68 \%$ of total variation of SPM as revealed by means of PCA determining the selective response of target species (37, 20 and 9 percent). Plotting target species as spectral variables one compact group was formed and some outliers stand apart (Figure 2).

\subsection{Survival of Trichodermas in Liquid Formulations}

The LP PQ was not phytotoxic in therapeutic doses, but commercial LP proved to be harmful when applied as leaf spray independently on the emulsifiers. Both

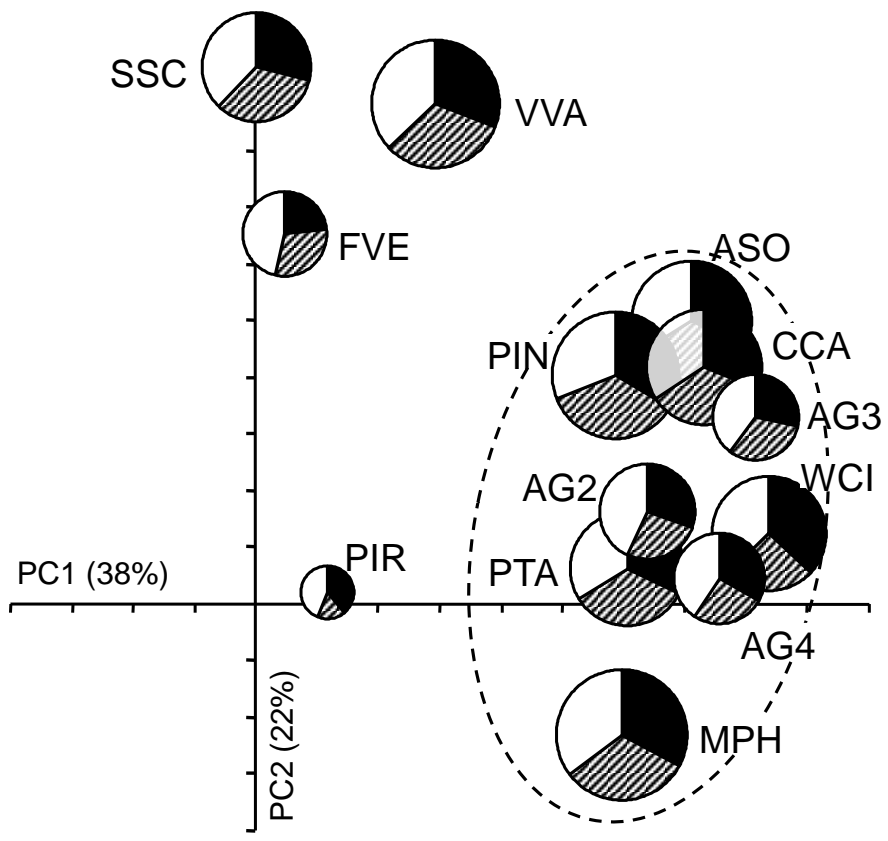

Figure 2. Similarity of test fungi based on their growth responses to toxin composition released by Trichoderma strains into the medium. The codes refer to species listed in Table 2 . The size of pies is proportional to potential sensitivity to released mycotoxic substances, while the size of white, black and striped sectors relates to sensitivity responses to strains of Pachibasium, Longibrachiatum and Trichoderma sections, respectively. 
fungitoxic and phytotoxic contaminants of commercial LP could be eliminated with activated carbon [HPO]. All Trichoderma strains examined well tolerated the LP PQ (Table 3). However, their conidia lost vitality rapidly in commercial

Table 3. Tolerance of Trichoderma conidia to mineral oil formulations ${ }^{\mathrm{a}}$.

\begin{tabular}{|c|c|c|c|c|c|c|}
\hline \multicolumn{2}{|c|}{ Strains $^{\mathrm{b}}$} & \multicolumn{5}{|c|}{ Survival of preparations $\mathrm{s}^{\mathrm{b}}$ (days) } \\
\hline Code & Sect & $\mathrm{A}$ & $\mathrm{B}$ & $\mathrm{C}$ & $\mathrm{D}$ & $\mathrm{E}$ \\
\hline 318 & $\mathrm{H}$ & $>360$ & $12-66$ & $12-66$ & $7-31$ & $11-38$ \\
\hline 311 & $\mathrm{~L}$ & $>360$ & $10-52$ & $7-45$ & $3-45$ & $7-45$ \\
\hline 313 & $\mathrm{~L}$ & $>360$ & $9-17$ & $5-12$ & $1-2$ & $1-4$ \\
\hline 312 & $\mathrm{~L}$ & $>360$ & $9-17$ & $9-17$ & $1-4$ & $1-5$ \\
\hline 301 & $\mathrm{~L}$ & $>360$ & $12-66$ & $12-66$ & $5-38$ & $7-38$ \\
\hline 314 & $\mathrm{~L}$ & $>360$ & $10-52$ & $10-45$ & $2-45$ & $5-45$ \\
\hline 305 & $\mathrm{~L}$ & $>360$ & $17-180$ & $17-180$ & $4-57$ & $7-57$ \\
\hline 328 & $\mathrm{~L}$ & $>360$ & $>360$ & $>360$ & $360->360$ & $360->360$ \\
\hline 315 & $\mathrm{~L}$ & $>360$ & $52-80$ & $52-80$ & $17-38$ & $17-38$ \\
\hline 316 & $\mathrm{~L}$ & $>360$ & $9-45$ & $7-38$ & $1-5$ & $3-5$ \\
\hline 306 & $\mathrm{P}$ & $>360$ & $10-52$ & $10-45$ & $2-45$ & $5-45$ \\
\hline 307 & $\mathrm{P}$ & $>360$ & $17-52$ & $17-45$ & $8-17$ & $8-17$ \\
\hline 308 & $\mathrm{P}$ & $>360$ & $10-52$ & $10-52$ & $5-52$ & $7-52$ \\
\hline 309 & $\mathrm{P}$ & $>360$ & $9-17$ & $8-14$ & $1-2$ & $2-6$ \\
\hline 075 & $\mathrm{P}$ & $>360$ & $12-66$ & $12-66$ & $8-12$ & $8-17$ \\
\hline 325 & $\mathrm{P}$ & $>360$ & $360->360$ & $360->360$ & $180-360$ & $180-360$ \\
\hline 408 & $\mathrm{P}$ & $>360$ & $360->360$ & $360->360$ & $180->360$ & $180->360$ \\
\hline 317 & $\mathrm{P}$ & $>360$ & $>360$ & $>360$ & $>360$ & $>360$ \\
\hline 338 & $\mathrm{P}$ & $>360$ & $17-180$ & $17-180$ & $17-31$ & $17-31$ \\
\hline 339 & $\mathrm{P}$ & $>360$ & $12-66$ & $12-66$ & $6-10$ & $6-10$ \\
\hline 332 & $\mathrm{P}$ & $>360$ & $>360$ & $>360$ & $180-360$ & $180-360$ \\
\hline 331 & $\mathrm{P}$ & $>360$ & $52-80$ & $52-80$ & $17-38$ & $17-45$ \\
\hline 310 & $\mathrm{P}$ & $>360$ & $180-360$ & $180-360$ & $45-66$ & $45-66$ \\
\hline 320 & $\mathrm{~T}$ & $>360$ & $>360$ & $>360$ & $360->360$ & $360->360$ \\
\hline 396 & $\mathrm{~T}$ & $>360$ & $52-80$ & $45-80$ & $45-80$ & $45-80$ \\
\hline 322 & $\mathrm{~T}$ & $>360$ & $10-52$ & $9-59$ & $6-17$ & $8-17$ \\
\hline 340 & $\mathrm{~T}$ & $>360$ & $10-24$ & $10-24$ & $6-9$ & $6-9$ \\
\hline 319 & $\mathrm{~T}$ & $>360$ & $9-17$ & $9-17$ & $1-4$ & $2-6$ \\
\hline 302 & $\mathrm{~T}$ & $>360$ & $52-80$ & $52-80$ & $17-66$ & $24-66$ \\
\hline 303 & $\mathrm{~T}$ & $>360$ & $6-9$ & $6-9$ & $1-4$ & $1-4$ \\
\hline 304 & $\mathrm{~T}$ & $>360$ & $7-24$ & $7-24$ & $3-5$ & $3-5$ \\
\hline 333 & $\mathrm{~N}$ & $>360$ & $12-66$ & $12-66$ & $10-38$ & $10-38$ \\
\hline
\end{tabular}

${ }^{a}$ Composition of preparations tested: A = Paraffin oil PH V., B and C = Paraffin oil, Atloxplus 300F (Uniquema), Tween 20 (Reanal), Hostaphat KLM (Clariant, Swiss), Alcanol-polyglycol-ether (EO:15) (Clariant), lecithin (Merck), ( $\mathrm{D}$ = Vektafid (Rogátor Kft., Hungary), $\mathrm{E}$ = Spraypover (Fine Agrochemicals Ltd., UK). ${ }^{b}$ Codes and sections: see Table 2. ${ }^{c}$ Limits of time (days) requested for decrease to 100 living cells per $\mathrm{ml}$ or destruction of all conidia in the preparation, respectively. 
pesticides even in cases, when the active ingredient did not possess fungicidal activity due to toxicity of carriers and surfactants [14] or impurities of liquid carriers. We have tested the shelf life of Trichoderma strains storing their conidia in liquid formulations that meet requirements of application (Table 3). The surfactants heavily and strain dependent manner influenced the survival of conidia. Nevertheless, some strains exhibited high tolerance, and these were selected for field applications.

\subsection{Results of Foliar Applications}

The liquid formulations were significantly more efficient against rose black spot disease either evaluated by incidence of spots or distribution in canopy, with special regard to T. harzianum strains (Table 4). The strains of phylloplane origin also proved to be more efficient, independently of their taxonomic position, even in solid formulations. However, only two of them were as active as the chemical control (combination of Benlate and Tilt in doses recommended by producers). The amount of liquid formulations to be applied as leaf spray could be reduced in two order of magnitude as compared to the solid preparations to achieve the same effect. The application of optimized liquid preparation based on phylloplane originated $T$. harzianum that exhibited high activity against some pepper diseases lessened the yield loss to economically acceptable level with significant increase of the quality of product (Table 5). The plants were wilted mainly by Macrophomina infection, Rhizoctonia and Fusarium were presented in few suppressed plants as well. The Alternaria infection was sporadic, while Phytophtora, Pythium and TSPW occurred only in control plots. The soil treatment of frames with P408 wettable powder significantly enhanced the quality of fruits.

Table 4. Efficacy of biopreparations against rose black spot disease.

\begin{tabular}{|c|c|c|c|c|c|c|c|}
\hline \multirow{2}{*}{\multicolumn{2}{|c|}{ Strains in formule }} & \multirow{2}{*}{\multicolumn{2}{|c|}{ Control $^{\mathrm{a}}$}} & \multicolumn{4}{|c|}{ Preparations ${ }^{\mathrm{b}}$} \\
\hline & & & & \multicolumn{2}{|c|}{$1 / \mathrm{A}$} & \multicolumn{2}{|c|}{$2 / \mathrm{B}$} \\
\hline Code & Sect. & $\mathrm{C}^{\mathrm{c}}$ & $\mathrm{A}^{\mathrm{d}}$ & $\mathrm{C}$ & A & $\mathrm{C}$ & $\mathrm{A}$ \\
\hline 075 & $\mathrm{P}$ & $1-13$ & 100 & $0-8$ & 37 & $0-11$ & 98 \\
\hline 317 & $\mathrm{P}$ & $0-15$ & 97 & $0-3$ & 35 & $0-9$ & 87 \\
\hline 325 & $\mathrm{P}$ & $0-14$ & 98 & $0-4$ & 12 & $0-11$ & 71 \\
\hline 328 & $\mathrm{~L}$ & $1-11$ & 100 & $0-3$ & 9 & $0-12$ & 47 \\
\hline 396 & $\mathrm{~T}$ & $1-10$ & 100 & $0-1$ & 2 & $0-6$ & 55 \\
\hline 408 & $\mathrm{P}$ & $0-12$ & 99 & $0-2$ & 4 & $0-10$ & 76 \\
\hline \multicolumn{2}{|c|}{ Density of spray } & \multicolumn{2}{|c|}{ not } & \multicolumn{2}{|c|}{$2.5 \times 10^{3}$ cell $\mathrm{mL}^{-1}$} & \multicolumn{2}{|c|}{$5 \times 10^{4}$ cell $\mathrm{mL}^{-1}$} \\
\hline
\end{tabular}

${ }^{\mathrm{a}}$ Control = Paraffin oil with surfactants; ${ }^{\mathrm{b} P r e p a r a t i o n s: ~} 1 / \mathrm{A}=$ Paraffin oil based preparation proceeded by patent application [17], 2/b Tapioka starch supported preparation containing Lecithin and fatty alkanolpolyglycolether (EO:05); ${ }^{\mathrm{c}}$ Minimum and maximum number of colonies on a single leaf; ${ }^{\mathrm{d}} \mathrm{A}=$ ratio of infected leaves in the canopy of rose bush. 
Table 5. Protective effect of Trichoderma harzianum P408 strain on green pepper.

\begin{tabular}{|c|c|c|c|c|c|c|c|}
\hline \multirow{2}{*}{ Treatment $^{c}$} & \multicolumn{6}{|c|}{ Quality Classes $^{\mathrm{a}}$} & \multirow{2}{*}{ Destroyed } \\
\hline & Extra & I. & II. & III. & Injured & Yield $^{\mathrm{d}}$ & \\
\hline Control $^{\mathrm{b}}$ & 6 & 13 & 54 & 16 & 11 & 100 & $21-44$ \\
\hline OP & 5 & 12 & 55 & 13 & 16 & 101 & $25-38$ \\
\hline $\mathrm{TT}$ & 6 & 12 & 52 & 15 & 15 & 106 & $23-44$ \\
\hline $\mathrm{TT}+\mathrm{OP}$ & 5 & 16 & 56 & 9 & 13 & 109 & $19-45$ \\
\hline $\mathrm{TP}$ & 10 & 28 & 40 & 11 & 11 & 125 & $17-24$ \\
\hline OTP & 8 & 25 & 56 & 8 & 4 & 148 & $18-27$ \\
\hline $\mathrm{TT}+\mathrm{OP}$ & 8 & 26 & 63 & 2 & 2 & 152 & $17-21$ \\
\hline $\mathrm{TT}+\mathrm{OTP}$ & 11 & 25 & 60 & 2 & 1 & 171 & $0-6$ \\
\hline
\end{tabular}

${ }^{a}$ Meets up the requirements of engrossers. ${ }^{b}$ Nursed following traditional rules. ${ }^{\mathrm{c} F o l l o w i n g}$ control programs were carried out: $\mathrm{OP}=$ Sprayed with paraffin oil, TT $=$ Preplanting soil treatment with P408 wp $\left(1 \mathrm{~g} \cdot \mathrm{sqm}^{-1}\right)$, $\mathrm{OTP}=$ Sprayed with liquid $P 408$ formule $\left(1 \mathrm{~mL} \cdot \mathrm{sqm}^{-1}\right)$, and the combined treatments TT $+\mathrm{OP}$, TT $+\mathrm{TP}$ and TT + OTP. ${ }^{\mathrm{d}}$ The number of fruits harvested. ${ }^{\mathrm{e}}$ Minimum and maximum number of wilted stools of 250 during the vegetation.

\section{Discussion}

The present evaluation gave clear indication that the isolates of T. atroviride, $T$. harzianum and $T$. parceramosum isolated from bodies of phyllosphere parasiting fungi are strong and virulent antagonists, which can be effectively used in the management of both soil and airborne fungal diseases. Combination of soil application and leaf sprays with Trichoderma based biopreparate appears to be the most effective one, however, the increased quality and quantity of the yield in treated pepper plants may be due to the production of plant growth promoters or through indirect stimulation of nutrient uptake as well. The producton of siderophores also should be taken into consideration.

The effect of Trichoderma against other plant associated microorganisms, especially against those that are beneficial to crops, should also be investigated.

\section{Conclusions}

In commercial LP the shelf life of conidia significantly decreased in strain dependent manner, and it was phytotoxic when applied as leaf spray independently on the emulsifiers. Both fungitoxic and phytotoxic contaminants of commercial LP could be eliminated with activated carbon.

The amount of liquid formulation of phylloplane originated T. atroviride, $T$. harzianum and T. parceramosum strains to be applied as leaf spray could have been reduced in two order of magnitude as compared to the solid preparations to achieve the same effect against rose black spot.

Even one soil treatment with low level of Trichoderma propagules results economically measurable effect on the yield of target plants.

The application of optimized liquid preparation containing carefully selected, phylloplane originated T. harzianum strain lessened the yield loss to economically acceptable level with significant increase of the quality of product and re- 
sulted impressive increase of financial benefit.

Further studies are requested to reveal factors determining the selective response of target fungi as well as selective action of antagonists.

\section{Acknowledgements}

This work was supported by the Hungarian Scientific Research Fund (OTKA) F67908 and by The National Office for Research and Technology, Grant No. K67688.

\section{References}

[1] Weindling, R. (1932) Trichoderma lignorum as a Parasite of Other Soil Fungi. Phytopathology, 22, 837-845.

[2] Weindling, R. and Fawcett, H.S. (1934) Experiments in Biological Control of Rhizoctonia Damping-off. [Abstract.] Phytopathology, 24, 1142.

[3] Harman, E.G. (2006) Overview of Mechanisms and Uses of Trichoderma spp. Phytopathology, 96, 190-194. https://doi.org/10.1094/PHYTO-96-0190

[4] Mukherjee, P.K., Horwitz, B.A., Singh, U.S., Mukherjee, M. and Schmoll, M. (2013) Trichoderma in Agriculture, Industry and Medicine: An Overview. In: Prasun, K., Mukherjee, B.A., Horwitz, Singh Mala Mukherjee, U.S. and Schmoll, M., Eds., Trichoderma: Biology and Applications, CABI, Oxford, 1-10. https://doi.org/10.1079/9781780642475.0001

[5] Gupta, V.K., Schmoll, M., Herrera-Estrella, A., Upadhyay, R.S., Druzhinina, I. and Tuohy, M. (2014) Biotechnology and Biology of Trichoderma. Elsevier, UK.

[6] Papavizas, G.C. (1985) Trichoderma and Gliocladium: Biology, Ecology, and Potential for Biocontrol. Annual Review of Phytopathology, 23, 923. https://doi.org/10.1146/annurev.py.23.090185.000323

[7] Herrera-Estrella, A. and Chet, I. (2004) The Biological Control Agent Trichoderma-From Fundamentals to Applications. In: Arora, D.K., Ed., Fungal Biotechnology in Agricultural, Food and Environmental Applications, Marcel Dekker, New York, 147-156.

[8] Vinale, F., Sivasithamparam, K., Ghisalberti, E.L., Marra, R., Woo, S.L. and Lorito, M. (2008) Trichoderma-Plant-Pathogen Interactions. Soil Biology \& Biochemistry, 40, 1-10. https://doi.org/10.1016/j.soilbio.2007.07.002

[9] Rollan, M., Monaco, C. and Nico, A. (1999) Effecto de la emperatura sobre la interaccion in vitro entre especies de Trichoderma y Sclerotinia sclerotiorum, $S$. minor y Sclerotium rolfsii. Investigationes agraria. Production y protection de vegetales, $14,33-48$.

[10] Naár, Z. (2007) Ecological Evaluation of Factors Influencing the Soil Colonization of Antagonistic Trichoderma Species. PhD Thesis, Hungarian Academy of Sciences, Budapest.

[11] Woo, S.L., Ruocco, M., Vinale, F., Nigro, M., Marra, R., Lombardi, N., Pascale, A., Lanzuise, S., Manganiello, G. and Lorito, M. (2014) Trichoderma-Based Products and Their Widespread Use in Agriculture. Open Mycology Journal, 8, 71-126. https://doi.org/10.2174/1874437001408010071

[12] Kövics, G.J., Harz, P. and Naár, Z. (2001) Biological Control against Rhizoctonia Damping-off Disease of Tomato by Trichoderma Strains. Bulletin of the University of Agricultural Sciences and Veterinary Medicine Cluj-Napoca Horticulture, 55-56, 63-68. 
[13] Naár, Z. and Dobos, A. (2006) Redundancy Analysis of the Influence of Metal Content and Other Edaphic Parameters on the Coexsistence of Trichoderma Species. Applied Ecology and Environmental Research, 4, 113-123. http://www.aloki.hu/pdf/0402 113123.pdf

[14] Oros, G., Naár, Z. and Cserháti, T. (2011) Growth Response of Trichoderma Species to Organic Solvents. Molecular Informatics, 30, 276-285. https://doi.org/10.1002/minf.201000097

[15] Druzhinina, I. and Kubicek, C. (2005) Species Concepts and Biodiversity in Trichoderma and Hypocrea: From Aggregate Species to Species Clusters? Journal of Zhejiang University Science B, 6, 100-112. https://doi.org/10.1631/jzus.2005.B0100

[16] Cumagun, C.J.R. (2014) Advances in Formulation of Trichoderma for Biocontrol. In: Gupta, V.K., Schmoll, M., Herrera-Estrella, A., Upadhyay, R.S., Druzhinina, I. and Tuohy M., Eds., Biotechnology and Biology of Trichoderma, Chapter 39, Elsevier, Amsterdam, 527-532. https://doi.org/10.1016/b978-0-444-59576-8.00039-4

[17] Oros, G. and Naár, Z. (2008) Environment Friendly Biomicrobicides and Their Use. HPO 0800405.

[18] Oros, G. and Ujváry, I. (1999) Botanical Fungicides: Natural and Semi-Synthetic Ceveratrum Alkaloids. Pesticide Science, 55, 253-264. https://doi.org/10.1002/(SICI)1096-9063(199903)55:3<253::AID-PS926>3.0.CO;2-6

[19] Askew, D.J. and Laing, M.D. (1993) An Adapted Selective Medium for the Quantitative Isolation of Trichoderma Species. Plant Patholology, 42, 686-690. https://doi.org/10.1111/j.1365-3059.1993.tb01553.x

[20] Andrews, S. and Pitt, J.I. (1986) Selective Medium for Isolation of Fusarium Species and Dematiaceous Hyphomycetes from Cereals. Applied and Environmental Microbiology, 51, 1235-1238. https://www.ncbi.nlm.nih.gov/pmc/articles/PMC239051/pdf/aem00141-0091

[21] Mihail, J.D. and Alcorn, S.M. (1982) Quantitative Recovery of Macrophomina phaseolina Sclerotia from Soil. Plant Disease, 66, 662-663. https://doi.org/10.1094/PD-66-662

[22] Conway, K.E. (1985) Selective Medium for Isolation of Pythium spp. from Soil. Plant Disease, 69, 393-395. https://doi.org/10.1094/PD-69-393

[23] Trujillo, E.E., Cavin, C.A. Aragaki, M. and Yoshimura, M.A. (1987) Ethanol-Potassium Nitrate Medium for Enumerating Rhizoctonia solani-like Fungi from Soil. Plant Disease, 71, 1098-1100. https://doi.org/10.1094/PD-71-1098

[24] Lewi, P.J. (1976) Spectral Mapping, a Technique for Classifying Biological Activity Profiles of Chemical Compounds. Arzneimittelforschung, 26, 1295-1300. 
Submit or recommend next manuscript to SCIRP and we will provide best service for you:

Accepting pre-submission inquiries through Email, Facebook, LinkedIn, Twitter, etc. A wide selection of journals (inclusive of 9 subjects, more than 200 journals)

Providing 24-hour high-quality service

User-friendly online submission system

Fair and swift peer-review system

Efficient typesetting and proofreading procedure

Display of the result of downloads and visits, as well as the number of cited articles Maximum dissemination of your research work

Submit your manuscript at: http://papersubmission.scirp.org/

Or contact ajps@scirp.org 